\title{
Analisis Kemampuan Menulis dan Membaca Huruf Pada Anak Berkebutuhan Khusus Di SDN 1 Picungremuk
}

\author{
Lusi Andriyani ${ }^{1}$, Anggia Suci Pratiwi ${ }^{2}$, Sunanih ${ }^{3}$ \\ 1,2, 3 PGSD, FKIP, Universitas Muhammadiyah Tasikmalaya1, Jl. Tamansari No. KM 2,5 \\ Mulyasari, Kec. Tamansari, Tasikmalaya, Jawa Barat 461962 \\ Corresponding author's : 'lusiandriyani4@gmail.com, 2anggia@umtas.ac.id, \\ ${ }^{3}$ sunanihsyam@yahoo.co.id
}

\section{Analysis of Ability to Write and Read Letters in Children With Special Needs at SDN 1 Picungremuk}

\section{Kata Kunci}

Kemampuan Menulis, Kemampuan Membaca, Anak berkebutuhan khusus (ABK).

\section{Keywords:}

Writing Ability, Reading Ability, Children with special needs (ABK).

\begin{abstract}
Abstrak
Berdasarkan hasil observasi di kelas V SDN 1 Picungremuk, menunjukkan bahwa dalam proses pembelajaran guru belum menggunakan metode pembelajaran yang tepat sehingga pembelajaran kurang menarik dan peserta didik menganggap menulis dan membaca adalah pelajaran yang sulit. Tujuan penelitian ini untuk mengetahui perkembangan menulis dan membaca Anak Berkebutuhan Khusu, untuk mengetahui perkembangan Anak Berkebutuhan Khusu setelah diberikan media kartu bergambar selama penlitian. Metode yang digunakan dalam penelitian ini adalah penelitian kualitatif dengan pendekatan Grounded theory yaitu menghasilkan penjelasan umum dari sebuah proses, peneliti fokus pada proses atau tindakan yang berbeda dari waktu ke waktu, mengembangkan teori dari proses atau tindakan tersebut, membuat catatan untuk dikumpulkan dan dianalisi, melakukan wawancara, dan analisi data. Hasil temuan yang didapatkan bahwa penggunaan media pada pengenalan huruf $A-Z$ pada Anak Berkebutuhan Khusus bias berjalan dengan baik melalui berbagai tahapan dan pendekatan, terciptanya suasana belajar belajar yang menyenangkan dan menarik. Meskipun anak masih mengalami kesulitan dalam mengingat hurruf, tetapi sudah ada kemajuan dalam penulisan karena anak tersebut mengalami kebiasaan dalam penulisan huruf tersebut.
\end{abstract}

Abstract:
Based on the results of observations in class V SDN 1 Picungremuk, it
shows that in the learning process the teacher has not used the right
learning method so that learning is less interesting and students think
writing and reading is a difficult subject. The purpose of this study
was to determine the development of writing and reading for children
with special needs, to determine the development of children with
special needs after being given picture cards during the study. The
method used in this research is qualitative research with the Grounded
theory approach, which is to produce a general explanation of a
process, researchers focus on different processes or actions from time
to time, develop theories of these processes or actions, take notes to
be collected and analyzed, carry out interviews, and data analysis. The
findings showed that the use of media in recognizing the letters A-Z in
children with special needs can run well through various stages and
approaches, creating a fun and interesting learning atmosphere. Even
though the child still has difficulty remembering the letters, there has
been progress in writing because the child has a habit of writing these
letters

\section{PENDAHULUAN}

Anak berkebutuhan khusus adalah anak yang memiliki keunikan tersendiri dalam jenis dan karakteristiknya, yang membedakan dari anak-anak normal pada umumnya. Salah 
satunya yaitu anak yang mengalami hambatan atau retardasi mental adalah penurunan fungsi intelektual yang menyeluruh secara bermakna dan secara langsung menyebabkan gangguan adaptasi sosial, dan bermanifestasi selama masa perkembangan dan biasa disebut dengan anak tunagrahita. Anak tunagrahita adalah anak yang tidak mampu beradaptasi dengan lingkungan normal dan membutuhkan layanan, perawatan, supervisi, kontrol dan dukungan dari pihak luar. Klasifikasi anak tunagrahita meliputi anak tunagrahita ringan, sedang dan berat. Hal ini dilakukan untuk mempermudah dalam memberikan penanganan kepada anak agar mendapatkan layanan yang sesuai terutama dalam layanan pendidikannya.

Tunagrahita adalah individu yang menunjukkan fungsi kecerdasan umum di bawah rata-rata pada saat periode perkembangan dan berhubungan dengan kerugian adaptasi tingkah laku. Menurut Efendi, (2006: 89) seorang dikategorikan tunagrahita apabila kecerdasannya secara umum di bawah rata-rata dan mengalami kesulitan penyesuaian sosial dalam setiap fase perkembangannya. Kekurangan yang dialami anak tunagrahita yaitu pada keterampilan adaptif, antara lain kemampuan berkomunikasi, menolong diri, keterampilan sosial, pengarahan diri, keamanan diri, dan akademik. Subjek dalam penelitian ini adalah anak bernama Rafles Rizki Agung kurang berkonsentrasi dan lekas bosan, sering merasa malu. Anak tunagrahita sedang masih mempunyai potensi untuk dilatih menahan diri dan beberapa pekerjaan yang memerlukan latihan secara mekanis. Kemampuan yang dapat dikembangkan yaitu diberikan sedikit pelajaran menghitung, menulis, dan membaca yang fungsional untuk kehidupan sehari-hari sebagai bekal mengenal lingkungannya, serta latihan-latihan memelihara diri dan beberapa keterampilan sederhana.

Kemampuan yang harus dikuasai adalah menulis dan membaca yang sering di gunakan dalam kehidupan sehari-hari sebagai bekal untuk menghadapi lingkungannya, serta latihan-latihan sederhana lainnya, anak tunagrahita sedang merupakan anak yang mempunyai kecerdasan intelektual di bawah rata-rata, dan juga memerlukan pembelajaran khusus.

Pendidikan merupakan hak seluruh warga negara, tanpa membedakan asal-usul, status sosial ekonomi, tanpa terkecuali yang mempunyai kelainan atau tidak memiliki hak yang sama untuk memperoleh pendidikan. Pembelajaran dikelas sebisa mungkin dibuat flekasibel, terutama dalam media pembelajaran yang mempengaruhi asesmen belajar dikelas. Dengan mendesain media pembelajaran merupakan salah satu cara dalam melihat ketertarikan dan hasil kemampuan yang dicapai. Media pembelajaran merupakan segala bentuk perangsang dan alat yang disediakan guru untuk mendorong siswa belajar secara cepat, tepat, mudah, benar dan tidak terjadinya verbalisme. Media pembelajaran merupakan alat bantu bagi perserta didik dalam rangka memperoleh pengalaman belajar secara signifikan. Berdasarkan latar belakang diatas penulis memfokuskan untuk melakukan kegiatan penelitian tentang "Analisis kemampuan menulis dan membaca fonem pada Anak Berkebutuhan Khusus."

\section{METODE PENELITIAN}

Metode yang digunakan dalam penelitian ini adalah penelitian kualitatif. Moleong, (2007: 6). Metode kualitatif digunakan untuk dapat memperoleh suatu informasi yang mendalam tentang situasi yang dialami oleh subjek penelitian dimana yang digali adalah proses atau sesuatu yang melatar belakangi terjadinya sesuatu. Sugiyono, (2010:3).metode kualitatif digunakan untuk mendapatkan data yang mendalam, suatu data yang mengandung makna. Makna adalah data yang sebenarnya, data yang pasti yang merupakan suatu nilai di balik data yang tampak. Oleh karena itu, di dalam penelitian kualitatif tidak menekankan pada generalisasi, tetapi lebih menekankan pada makna.

Desain penelitian yang digunakan dalam penelitian ini adalah desain Grounded theory. Tohirin (2016:31) Grounded theory adalah desain penelitian kualitatif di mana peneliti menghasilkan penjelasan umum (teori) dari sebuah proses, tindakan, atau interaksi yang terbentuk oleh pandangan dari subjek atau partisipan. Penggunaan metode ini sesuai dengan nama yang disandangnya karena tujuan dari teori ini adalah teoritasi data, teoritasi data adalah sebuah metode penyusunan teori yang berorientasi tindakan/interaksi karena ini cocok digunakan untuk penelitian terhadap prilaku. Menurut Charmaz (2006:11) yang mendasari desain Grounded theory adalah pedoman yang sistematis namun fleksibel dalam mengumpulkan dan menganalisis data kualitatif yang bertujuan untuk membangun teori 'mendasar' dalam data itu sendiri. Grounded theory mengumpulkan data untuk dapat mengembangkan analisis teoritis dari awal penelitian. Peneliti berusaha mempelajari apa yang terjadi dilapangan dimana peneliti ikut serta didalamnya dan seperti apa kehidupan 
partisipan. Peneliti mempelajari bagaimana partisipan menjelaskan mengenai pendapat dan perilaku mereka (Charmaz, 2006).

\section{HASIL DAN PEMBAHASAN}

Implementasi Penggunaan Media Visual Kartu Bergambar dalam Mengenal huruf pada anak berkebutuhan khusus (ABK) di kelas V SDN 1 Picungremuk kepada 1 orang anak, dan melakukan wawancara kepada guru kelas yang bernama ibu Nunung.

Dalam penelitian ini terdapat tiga bahasan mengenai pengenal huruf pada anak berkebutuhan khusus di SDN 1 Picugremuk. Pertama adalah persiapan awal sebelum guru mengajar dengan menggunakan media kartu bergambar. Kedua adalah penggunaan kartu bergambar itu sendiri, dan yang ketiga evaluasi atau penelitian saat pembelajaran. Hal itu terlihat ketika peneliti melakukan observasi, ibu Nunung mempersiapkan pembelajaran tersebut. Kegiatan yang dilaksanakan tercantum pada rencana pelaksanaan pembelajarn harian. Dalam pembelajaran harian belum ada perlakuan khusus pada anak berkebutuhan khusu tersebut sehingga saat dilakukan pembelajaran, anak masih mengalami kesulitan dalam pembelajaran dan tertinggal oleh rekan-rekan lainnya.

Dari 20 kali penelitian anak tersebut dapat menuliskan huruf :

A dengan benar sebanyak $=10$ kali

B dengan benar sebanyak $=10$ kali

C dengan benar sebanyak $=10$ kali

D dengan benar sebanyak $=10$ kali

E dengan benar sebanyak $=8 \mathrm{kali}$

$\mathrm{F}$ dengan benar sebanyak $=9 \mathrm{kali}$

$\mathrm{G}$ dengan benar sebanyak $=9 \mathrm{kali}$

$\mathrm{H}$ dengan benar sebanyak $=9 \mathrm{kali}$

I dengan benar sebanyak = 5 kali

$\mathrm{J}$ dengan benar sebanyak $=7 \mathrm{kali}$

$\mathrm{K}$ dengan benar sebanyak $=6 \mathrm{kali}$

$L$ dengan benar sebanyak $=6$ kali

$M$ dengan benar sebanyak $=4$ kali

$\mathrm{N}$ dengan benar sebanyak $=5 \mathrm{kali}$

$O$ dengan benar sebanyak $=4 \mathrm{kali}$

$P$ dengan benar sebanyak $=4 \mathrm{kali}$

$\mathrm{Q}$ dengan benar sebanyak $=4 \mathrm{kali}$

$\mathrm{R}$ dengan benar sebanyak $=4$ kali

$\mathrm{S}$ dengan benar sebanyak $=2 \mathrm{kali}$

$T$ dengan benar sebanyak = 2 kali

$\mathrm{U}$ dengan benar sebanyak $=2 \mathrm{kali}$

$V$ dengan benar sebanyak $=-$

$W$ dengan benar sebanyak $=2$ kali

$X$ dengan benar sebanyak $=2$ kali

$Y$ dengan benar sebanyak $=1$ kali

$Z$ dengan benar sebanyak $=1$ kali 
Dari 20 kali penelitian anak tersebut dapat membaca huruf :

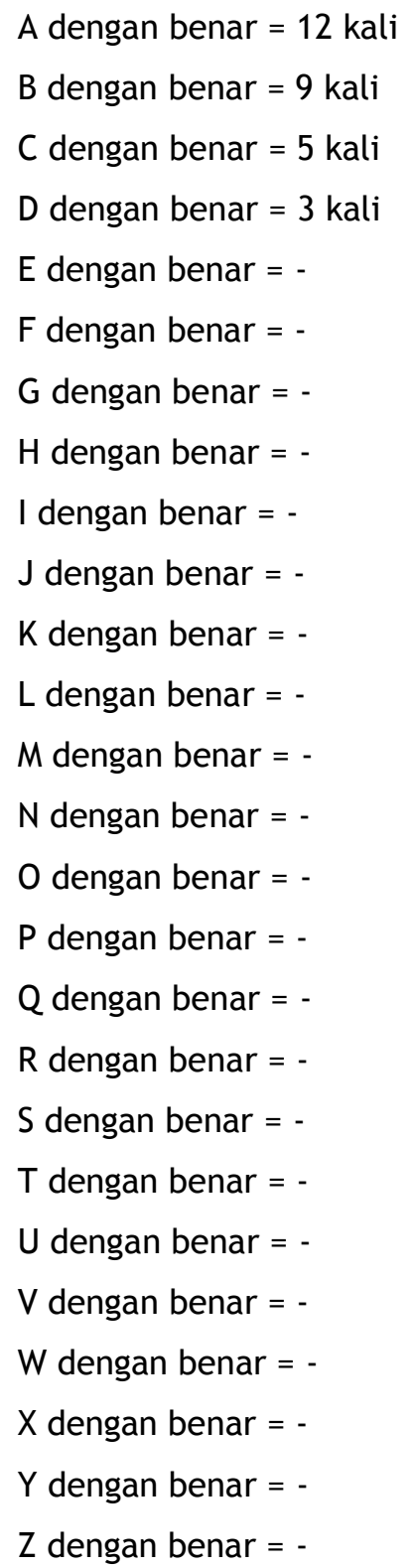

Hasil selama 20 hari melakuakn penelitian pengenalan menulis huruf dan membaca adalah: anak tersebut dapat mengingat kemampuan penulisan huruf hanya beberapa huruf saja dikarenakan anak tersebut sudah terbiasa dalam melakukan penulisan huruf-huruf tersebut, tetapi apabila anak tersebut diberikan perintah untuk membaca huruf, anak tersebut masih mengalami banyak kesulitan karena lupa dalam mengingat huruf tersebut.

\section{KESIMPULAN}

Dari hasil penelitian tentang Analisis Kemampuan Menulis dan membaca huruf Pada Anak Berkebutuhan khusus di SDN 1 Picungremuk dapat disimpulkan bahwa: Tentang pembelajaran kognitif menulis dan membaca anak berkebutuhan khusus. Tidak ada huruf yang muncul selalu benar, ada huruf yang muncul selalu salah, huruf $E, F, G, H, I, J, K, L, M$, $\mathrm{N}, \mathrm{O}, \mathrm{P}, \mathrm{Q}, \mathrm{R}, \mathrm{S}, \mathrm{T}, \mathrm{U}, \mathrm{V}, \mathrm{W}, \mathrm{X}, \mathrm{Y}, \mathrm{Z}$. ada huruf yang awal nya muncul benar menjadi salah huruf $A, B, C, D$. ada huruh yang awal nya salah menjadi benarada huruf yang awalnya benar menjadi salah, huruf D. Dari sini dapat di simpulkan bahwa anak tersebut hanya dapat menebak huruf-huruf yang disediakan oleh peneliti penggunaan media kartu bergambar dalam pengenalan huruf pada anak tunagrahita telah berjalan dengan baik dan benar bahwa penggunaan kartu gambar dapat melatih konsentrasi dan dapat menulis dengan melakukan kebiasaan menulis anak dapat mengingat tulisan huruf-huruf tersebut. Dimana pengenalan huruf adalah tahapan awal dalam kegiatan membaca. Namun untuk pengenalan huruf atau membaca huruf anak masih mengalami kesulitan karena anak hanya dapat mengingat apa 
yang terlintas dipikiranya dan tidak mengetahui huruf yang sebenarnya di tanyakan Adapun dalam penggunaan media visual kartu bergambar tersebut dapat peneliti simpulkan :

1. Langkah persiapan, merencanakan proses kegiatan pembelajaran dan menggunakan media visual kartu bergambar yang tepat bagi kelangsungan proses pembelajaran yang berguna dalam pengenalan huruf pada anak.

2. Pelaksanaan proses kegiatan belajar menggunakan media visual kartu bergambar dengan membagikan dan membuat kegiatan permainan kartu bergambar dengan menyenangkan.

3. Penilaian dilakukan untuk mengetahui kemampuan yang dimiliki oleh anak, dengan melakukan catatan harian atau catatan anekdot dan penilaian kepada anak selama proses pembelajaran.

\section{UCAPAN TERIMAKASIH}

Ucapan terima kasih kepada semua pihak yang telah membantu dalam pnyelesaian penelitian ini, dan khususnya kepada pembimbing dan staff dosen yang meluangkan waktunya untuk terus membimbing peneliti ke arah yang lebih baik.

\section{DAFTAR PUSTAKA}

Charmaz, K. (2006). Constructing Grounded Theory: A Practical Guided Through Qualitative Analysis London, : Creswell, J. W. . California, New Delhi Singapore: SAGE Publiction Ltd.

Moleong , L. (2007 ). Metodologi Penelitian Kualitatif. Edisi Revisi . Bandung : PT Remaja Rosdakarya .

sugiono . (2010). Statistika untuk Penelitian. Bandung: Alfabeta .

Tohirin . (2016). Metode Penelitian Kualitatif Dalam Pendidikan Dan Bimbingan Konseling . Jakarta : Rajawali Pers 